\title{
Formulasi dan Pengujian Aktivitas Antibakteri Krim Ekstrak Etanol Daun Kapuk (Ceiba pentandra L.)
}

Tiana Milanda*,1, Richie Agusta Iwan Chandra², Alam Jenuin Dwipratama ${ }^{1}$

\begin{abstract}
1Departemen Biologi Farmasi, Fakultas Farmasi, Universitas Padjadjaran, Jawa Barat, Indonesia 2Departemen Farmasetika dan Teknologi Farmasi, Fakultas Farmasi, Universitas Padjadjaran, Jawa Barat, Indonesia *E-mail: tiana.milanda@unpad.ac.id (Submit 15/4/2021, Revisi 11/5/2021, Diterima 16/5/2021, Terbit 25/5/2021)
\end{abstract}

\begin{abstract}
Abstrak
Jerawat merupakan penyakit inflamasi kronis pada kulit, yang diperparah oleh infeksi bakteri seperti Propionibacterium acnes dan Staphylococcus epidermidis. Banyaknya kasus resistensi bakteri menyebabkan perlunya antibakteri alternatif, antara lain dari tumbuhan kapuk (Ceiba pentandra L.). Penelitian ini bertujuan memperoleh sediaan krim dengan bahan aktif ekstrak etanol daun kapuk yang efektif terhadap bakteri penyebab jerawat dan stabil dalam penyimpanan. Penelitian dilakukan melalui tahap determinasi tumbuhan dan penyiapan simplisia, ekstraksi simplisia, penapisan fitokimia ekstrak, pengujian aktivitas antibakteri ekstrak, penentuan Konsentrasi Hambat Tumbuh Minimum (KHTM) ekstrak, orientasi basis krim, formulasi dan pengujian kualitas fisik sediaan krim, pengujian aktivitas antibakteri sediaan krim selama penyimpanan dan uji banding aktivitas antibakteri sediaan krim terhadap basis dan ekstrak. Hasil penelitian menunjukkan bahwa ekstrak etanol daun kapuk memiliki aktivitas antibakteri terhadap S. epidermidis ATTC 12228 dan $P$. acnes isolat klinik dengan KHTM sebesar 0,125\% dan $0,078 \%$ b/v. Sediaan krim diformulasi menggunakan basis $\mathrm{F} 02$ dengan penambahan ekstrak sebesar dua, tiga dan empat kali KHTM. Formula 1 (krim dengan 2x KHTM ekstrak) merupakan sediaan krim dengan kualitas fisik terbaik, karena tampilan organoleptis, pH dan viskositasnya stabil selama 30 hari pada suhu kamar serta tidak mengalami pemisahan fase selama satu tahun. Formula 3 (krim dengan 4x KHTM ekstrak) merupakan sediaan krim dengan aktivitas antibakteri terbaik, terutama terhadap $P$. acnes isolat klinik. Dari hasil penelitian ini diperoleh formula krim dengan kandungan ekstrak etanol daun kapuk yang efektif terhadap bakteri penyebab jerawat dan stabil selama penyimpanan.
\end{abstract}

Kata kunci: Jerawat, KHTM, Propionibacterium acnes, Staphylococcus epidermidis

\section{Pendahuluan}

Jerawat (acne vulgaris) merupakan penyakit inflamasi kronis pada kulit yang umumnya terjadi pada remaja, namun tidak jarang berlanjut sampai dewasa. Jerawat dapat mengganggu penampilan dan menurunkan kualitas hidup pasien, karena menyebabkan kecemasan, depresi, bahkan bunuh diri ${ }^{1}$. Beberapa bakteri dapat memperburuk kondisi jerawat, diantaranya Propionibacterium acnes ( $P$. acnes) dan Staphylococcus epidermidis (S. epidermidis)². 
P. acnes merupakan bakteri batang Gram negatif, yang merupakan flora normal pada kulit. Bakteri ini berubah menjadi patogen, jika berkembang biak secara anaerob dalam pori dan folikel kulit dengan menggunakan sebum trigliserida sebagai nutrisinya ${ }^{3}$. S. epidermidis merupakan bakteri kokus Gram positif yang bersifat anaerob fakultatif serta menyebabkan infeksi superfisial pada kelenjar sebaseus ${ }^{2}$.

Antibiotika oral atau senyawa keratolitikum sering digunakan untuk mengurangi hiperkeratinisasi, kolonisasi bakteri, produksi sebum dan inflamasi pada jerawat ${ }^{4}$. Antibiotika oral, seperti golongan tetrasiklin, trimetoprim-sulfametoksazol serta makrolida cukup efektif untuk mengobati jerawat ${ }^{5}$. Namun penggunaan antibiotik secara rutin sering menyebabkan efek samping, seperti gangguan mood, kulit kering, iritasi kulit dan resistensi antibiotik ${ }^{6}$. Penelitian terdahulu menunjukkan adanya berbagai galur $P$. acnes dan $S$. epidermidis yang resisten terhadap azitromisin, eritromisin, penisilin-G, tetrasiklin, klindamisin, amikasin, trimetoprim-sulfametoksazol dan rifampisin². Banyaknya galur resisten tersebut menyebabkan perlunya pencarian antibiotik alternatif, antara lain dari berbagai tumbuhan?

Kapuk (Ceiba pentandra L.) adalah tumbuhan tingkat tinggi yang banyak ditemukan di hutan hujan tropis. Ekstrak daun dan kulit batang tumbuhan ini digunakan secara tradisional untuk mengobati malaria, diabetes melitus, gonore, sifilis, infeksi saluran cerna, asma dan penyembuhan luka ${ }^{8}$. Ekstrak air dan etanol daun kapuk diketahui memiliki aktivitas antibakteri terhadap Staphylococcus aureus, Escherichia coli, Pseudomonas aeruginosa dan Klebsiella pneumoniae ${ }^{8,9}$. Penelitian lainnya menunjukkan aktivitas antibakteri berbagai ekstrak batang dan daun kapuk terhadap Mycobacterium fortuitum ATCC 684, Mycobacterium smegmatis ATCC 19420 dan Mycobacterium abcessus ATCC $19240^{10}$. Daun kapuk diketahui mengandung berbagai senyawa alkaloid, flavonoid, glikosida, protein, karbohidrat, gula tereduksi, aglikon steroidal, tanin, saponin, vitamin A, vitamin E, saponin, poliuronoid, polifenol, tanin dan plobatanin ${ }^{8}$.

Sampai saat ini, belum ada penelitian mengenai aktivitas antibakteri daun kapuk terhadap $P$. acnes dan $S$. epidermidis. Pada penelitian ini dilakukan formulasi sediaan krim yang mengandung ekstrak etanol daun kapuk dan pengujian aktivitasnya terhadap kedua bakteri tersebut. Sediaan krim dipilih, karena memberi kelembaban dan memiliki waktu kontak yang lebih lama dengan kulit, sehingga senyawa antibakteri yang terkandung di dalamnya dapat memberikan aktivitas yang lebih baik. Viscolam AT 100P, yang merupakan salah satu polimer golongan poliakrilat, dipilih sebagai pengental dan emulgator. Dari hasil penelitian ini diharapkan diperoleh formula krim dengan kandungan ekstrak daun kapuk yang efektif mengatasi jerawat dan stabil dalam penyimpanan. 


\section{Metode}

Alat

Alat yang digunakan berupa neraca analitik (Mettler Toledo AL204, Switzerland), maserator, rotary evaporator (Buchi Rotavapor R-300, Switzerland), penangas air (Memmert, Jerman), inkubator (Sakura IF-4, Jepang), mikropipet volume 10-100 $\mu \mathrm{L}$ (Biohit Proline, Finlandia), mikropipet volume 100-1000 $\mu \mathrm{L}$ (Socorex Acura 825, Switzerland), mikropipet adjustable 8-channel 50-300 $\mu \mathrm{L}$ (Eppendorf, Jerman), tip mikropipet biru dan kuning, 96-well microtiter plates (Iwaki, Jepang), oven (Memmert 400-800, Jerman), lemari pendingin, pH meter 744 (Methorm AG, USA), Programable Viscometer Brookfield DV II+ Pro (Brookfiled, USA), mikrosentrifugator (Sigma, Jerman) dan alat-alat yang umum digunakan di Laboratorium Farmasi Bahan Alam, Laboratorium Mikrobiologi serta Laboratorium Farmasetika.

\section{Bahan}

Daun kapuk segar diperoleh dari Indramayu, Jawa Barat. Bakteri uji S. epidermidis ATTC 12228 diperoleh dari Laboratorium Diagnostik PT. Biofarma, Bandung, Jawa Barat dan $P$. acnes isolat klinik dari Laboratorium Mikrobiologi, Universitas Jendral Ahmad Yani, Cimahi, Jawa Barat. Medium yang digunakan berupa Mueller Hinton Agar/MHA (Oxoid) dan Mueller Hinton Broth/MHB (Oxoid).

Bahan kimia lain yang digunakan terdiri dari etanol 95\% (Bratachem), natrium klorida (Merck), kloroform (Merck), amonia (Merck), amil alkohol (Merck), eter (Merck), asam klorida (Merck), asam sulfat (Merck), pereaksi Mayer (Bratachem), pereaksi Dragendorff (Bratachem), pereaksi Liebermann-Burchard (Bratachem), serbuk magnesium (Bratachem), kalium hidroksida (Merck), larutan standar Mc Farland 0,5, besi (III) klorida (Merck), gelatin (Bratachem), vanilin (Bratachem), dimetil sulfoksida/DMSO (Merck), natrium viscolam AT 100P (Nardev), propilenglikol (Bratachem), metil paraben (Bratachem), propil paraben (Bratachem) dan air suling.

\section{Prosedur Rinci}

1. Determinasi Tumbuhan dan Penyiapan Simplisia

Beberapa bagian tumbuhan kapuk dideterminasi di Laboratorium Taksonomi Tumbuhan, Jurusan Biologi, Fakultas Matematika dan IImu Pengetahuan Alam, Universitas Padjadjaran, Sumedang, Jawa Barat. Daun kapuk segar disortasi, dicuci dengan air mengalir dan dirajang sampai halus.

2. Ekstraksi Simplisia

Daun kapuk diekstraksi menggunakan metode maserasi ${ }^{11}$. Sebanyak $200 \mathrm{~g}$ rajangan daun kapuk direndam dalam $1 \mathrm{~L}$ etanol 95\% selama $3 \times 24$ jam. Setiap 24 jam ekstrak ditampung, lalu pelarut diganti dengan pelarut baru dalam jumlah sama. Pelarut diuapkan menggunakan rotary evaporator pada suhu $40^{\circ} \mathrm{C}$, lalu dipekatkan di atas penangas air pada suhu $60^{\circ} \mathrm{C}$. Ekstrak kental daun kapuk diamati secara organoleptis, lalu ditentukan rendemennya. 
3. Penyiapan Suspensi Bakteri Uji

S. epidermidis ATTC 12228 dan $P$. acnes isolat klinik ditumbuhkan pada MHA, lalu diinkubasi pada suhu $37^{\circ} \mathrm{C}$ selama $18-24$ jam. Kedua biakan disuspensikan dalam larutan natrium klorida fisiologis. Kekeruhan suspensi bakteri disesuaikan dengan kekeruhan larutan standar McFarland 0,5, yang setara dengan $1,5 \times 10^{8} \mathrm{CFU} / \mathrm{mL}^{13}$.

4. Pengujian Aktivitas Antibakteri Ekstrak

Aktivitas antibakteri ekstrak etanol daun kapuk ditentukan melalui metode difusi agar dengan teknik perforasi ${ }^{13}$. Ekstrak dilarutkan dalam DMSO 2\% v/v untuk menghasilkan berbagai konsentrasi.

Sebanyak $20 \mu \mathrm{L}$ suspensi bakteri dimasukkan ke dalam cawan petri, lalu ditambahkan $20 \mathrm{~mL}$ MHA yang masih cair. Cawan digoyang perlahan, lalu medium dibiarkan memadat pada suhu kamar. Medium dilubangi menggunakan perforator berdiamater $6 \mathrm{~mm}$, lalu dimasukkan $50 \mu \mathrm{L}$ larutan ekstrak. Sebagai kontrol, disiapkan cawan petri berisi MHA (kontrol negatif), MHA yang diinokulasi bakteri uji (kontrol positif) serta MHA yang diinokulasi DMSO $2 \% \mathrm{v} / \mathrm{v}$ (kontrol pelarut). Seluruh cawan diinkubasi pada suhu $37^{\circ} \mathrm{C}$ selama $18-24$ jam. Daerah hambat yang terbetuk di sekitar lubang, diukur menggunakan jangka sorong.

5. Penentuan KHTM Ekstrak

KHTM ekstrak etanol daun kapuk ditentukan dengan metode mikrodilusi ${ }^{13}$. Larutan stok ekstrak disiapkan dalam dua konsentrasi yang masih mempunyai aktivitas bakteri. Suspensi bakteri uji diencerkan 20 kali dengan larutan natrium klorida fisiologis, sehingga diperoleh inokulum yang setara dengan $5 \times 10^{6} \mathrm{CFU} / \mathrm{mL}$

Kolom pertama sampai dua belas pada microplate diisi dengan $100 \mu \mathrm{L}$ MHB. Kolom kedua dan ketiga diisi dengan $100 \mu \mathrm{L}$ larutan stok ekstrak, lalu campuran dihomogenkan dengan cara pipetting. Pengenceran bertingkat dilakukan dengan memipet $100 \mu \mathrm{L}$ dari kolom ketiga ke kolom keempat, lalu selanjutnya sampai kolom ke sebelas. Sebanyak $100 \mu \mathrm{L}$ dari kolom kedua dan kesebelas dibuang. Dengan cara ini, maka kolom ketiga berisi larutan ekstrak dengan konsentrasi tertinggi, sedang kolom kesebelas berisi larutan ekstrak dengan konsentrasi terendah.

Sebanyak $10 \mu \mathrm{L}$ suspensi bakteri uji ditambahkan pada kolom ketiga sampai kolom ke dua belas. Kolom pertama berfungsi sebagai kontrol negatif, kolom kedua sebagai kontrol ekstrak, sedangkan kolom kedua belas sebagai kontrol positif. Microplate ditutup menggunakan plastik selofan, lalu diinkubasi selama 18-24 jam pada suhu $37^{\circ} \mathrm{C}$. Konsentrasi terkecil ekstrak teraktif yang tetap bening (tidak ada pertumbuhan bakteri) ditetapkan sebagai nilai KHTM. 
6. Orientasi Basis Krim

Tiga basis krim $\left(\mathrm{FO}_{1}, \mathrm{FO}_{2}\right.$ dan $\left.\mathrm{FO}_{3}\right)$ diformulasi dengan variasi konsentrasi natrium viscolam AT 100P (Tabel 1). Air suling ditambahkan pada natrium viscolam AT 100P, lalu ditambahkan sedikit demi sedikit propilenglikol, metil paraben dan propil paraben. Campuran diaduk menggunakan mechanical stirrer sampai terbentuk emulsi minyak dalam air. Ketiga basis disimpan pada suhu kamar selama 7 hari, lalu diamati perubahan bentuk, konsistensi, warna, dan bau setiap hari selama satu minggu. Basis yang paling baik digunakan sebagai basis krim untuk formulasi krim antijerawat dengan ekstrak kapuk.

Tabel 1. Formula Basis Krim

\begin{tabular}{lccc}
\hline \multicolumn{1}{c}{ Komponen } & $\mathrm{FO}_{1}(\% \mathrm{~b} / \mathrm{v})$ & $\mathrm{FO}_{2}(\% \mathrm{~b} / \mathrm{v})$ & $\mathrm{F0}_{3}(\% \mathrm{~b} / \mathrm{v})$ \\
\hline Natrium viscolam & 5 & 10 & 15 \\
AT 100P & & 10 & 10 \\
Propilenglikol & 10 & 0,3 & 0,3 \\
Metil paraben & 0,3 & 0,6 & 0,6 \\
Propil paraben & 0,6 & 100 & 100 \\
Air suling sampai & 100 & & \\
\hline
\end{tabular}

7. Formulasi dan Pengujian Kualitas Fisik Sediaan Krim

Tiga sediaan krim diformulasi menggunakan basis terpilih dengan variasi penambahan ekstrak sebanyak 2, 3, dan 4 kali KHTM. Terhadap basis krim formula $\mathrm{FO}_{2}$, ditambahkan ekstrak dengan konsentrasi: $\mathrm{F} 1$ (2 kali KHTM), F2 (3 kali KHTM) dan F 3 (4 kali KHTM). Ekstrak dilarutkan dalam beberapa tetes etanol sebagai pelarut, yang telah dicampur dengan propilen glikol sebagai cosovent. Basis krim terpilih ditambahkan sedikit demi sedikit ke campuran tersebut, sambil diaduk menggunakan mechanical stirrer sampai terbentuk massa yang homogen. Sediaan krim dievaluasi selama 30 hari pada suhu kamar meliputi ${ }^{15}$ :

a. Pengamatan Organoleptis

Pengamatan organoleptis dilakukan terhadap perubahan bentuk, tekstur, warna dan bau krim pada hari ke-1, 3, 7, selanjutnya setiap minggu selama 30 hari.

b. Pengamatan Perubahan $\mathrm{pH}$

Sebanyak $1 \mathrm{~g}$ krim dilarutkan dalam $10 \mathrm{~mL}$ air suling, lalu $\mathrm{pH}$ larutan diukur tiga kali menggunakan $\mathrm{pH}$ meter. Pengukuran dilakukan pada hari ke-1, 3, 7, dan selanjutnya setiap minggu selama 30 hari.

c. Pengamatan Perubahan Viskositas

Sebanyak $2 \mathrm{~g}$ krim ditempatkan dalam wadah pengujian. Pengukuran viskositas dilakukan menggunakan spindle S-64 dengan kecepatan 20 rpm. Pengukuran dilakukan sebanyak tiga kali pada hari ke-1, 3, 7, dan selanjutnya setiap minggu selama 30 hari. 
d. Pengamatan Pemisahan Emulsi

Sebanyak $1 \mathrm{~g}$ krim disentrifugasi pada kecepatan 2.500, 3.000 dan $3.750 \mathrm{rpm}$ selama 5 jam di suhu kamar. Pengamatan dilakukan terhadap pemisahan fasa air dan fasa minyak.

8. Pengujian Aktivitas Antibakteri Sediaan Krim Selama Penyimpanan

Penentuan aktivitas antibakteri dilakukan terhadap F1, F2 dan F3 pada hari ke-1, ke-14 dan ke-30 melalui metode difusi agar dengan teknik perforasi ${ }^{13}$. Diameter hambat yang terbentuk diukur menggunakan jangka sorong.

9. Uji Banding Aktivitas Antibakteri Sediaan Krim terhadap Basis dan Ekstrak Aktivitas antibakteri ketiga sediaan krim dibandingkan terhadap basis dan ekstrak menggunakan metode difusi agar dengan teknik perforasi ${ }^{13}$. Diameter hambat yang terbentuk diukur menggunakan jangka sorong.

\section{Hasil}

\section{Hasil Determinasi Tumbuhan dan Penyiapan Simplisia}

Hasil determinasi menunjukkan bahwa tumbuhan yang digunakan adalah kapuk (Ceiba pentandra L.) dari keluarga Bombacaceae, ordo Malvales, kelas Magnoliopsida dan divisi Magnoliopsida.

\section{Hasil Ekstraksi Simplisia}

Dari ekstraksi $200 \mathrm{~g}$ simplisia daun kapuk, diperoleh ekstrak kental berwarna hijau tua, berbau khas dan berasa pahit, dengan rendemen ekstrak sebesar 9,135\% b/v.

\section{Hasil Pengujian Aktivitas Antibakteri Ekstrak}

Konsentrasi ekstrak yang digunakan adalah 50, 40, 30, 20, dan $10 \% \mathrm{~b} / \mathrm{v}$. Dari hasil pengujian diketahui bahwa ekstrak etanol daun kapuk memiliki aktivitas terhadap $S$. epidermidis ATTC 12228 dan P. acnes isolat klinik sampai konsentrasi 10 \% b/v.

\section{Hasil Penentuan KHTM Ekstrak}

Konsentrasi larutan stok ekstrak yang digunakan adalah 8 dan 10\% b/v. Nilai KHTM ekstrak etanol daun kapuk terhadap S. epidermidis ATTC 12228 dan $P$. acnes isolat klinik berturut-turut sebesar 0,125 dan $0,078 \% \mathrm{~b} / \mathrm{v}$ (Tabel 2). KHTM ekstrak yang digunakan dalam formulasi sediaan krim adalah $0,125 \% \mathrm{~b} / \mathrm{v}$, karena pada konsentrasi tersebut ekstrak masih mempunyai aktivitas terhadap kedua bakteri uji. 
Tabel 2. Hasil penentuan KHTM Ekstrak terhadap Bakteri Uji

\begin{tabular}{cccc}
\hline Larutan stok & Pengenceran & \multicolumn{2}{c}{ Pertumbuhan } \\
\cline { 3 - 4 } $\begin{array}{c}\text { ekstrak } \\
\text { larutan stok })\end{array}$ & $\begin{array}{c}\text { S. epidermidis } \\
\text { ekstrak }(\% \text { b/v })\end{array}$ & ATCC 12228 & $\begin{array}{c}\text { P. acnes } \\
\text { isolat klinik }\end{array}$ \\
\hline & 5,000 & - & - \\
2,500 & - & - \\
& 1,250 & - & - \\
10 & 0,625 & - & - \\
& 0,313 & - & - \\
& 0,156 & - & - \\
& 0,078 & + & + \\
& 0,039 & + & + \\
0,020 & + & - \\
& 4,000 & - & - \\
& 2,000 & - & - \\
& 1,000 & - & - \\
& 0,500 & - & - \\
& 0,250 & - & + \\
& 0,125 & - & + \\
& 0,063 & + & + \\
\hline
\end{tabular}

Keterangan :

$+=$ ada pertumbuhan koloni

- = tidak ada pertumbuhan koloni

\section{Hasil Orientasi Basis Krim}

Dari hasil pengamatan organoleptis, diketahui bahwa ketiga basis krim tidak mengalami perubahan bentuk, konsistensi, warna dan bau selama 7 hari pada suhu kamar (Tabel 3). $\mathrm{FO}_{2}$ dengan konsentrasi natrium viscolam AT100P $10 \% \mathrm{~b} / \mathrm{v}$ dipilih sebagai basis untuk penelitian selanjutnya, karena konsistensi lebih baik dari kedua basis lainnya. $\mathrm{FO}_{1}$ mempunyai bentuk terlalu berair, sedangkan $\mathrm{FO}_{3}$ terlalu berminyak. 
Tabel 3. Hasil Pengamatan Organoleptis Basis Krim Selama 7 Hari

\begin{tabular}{clccccccc}
\hline Formula & Karakteristik & \multicolumn{7}{c}{ Perubahan pada hari ke- } \\
\cline { 3 - 9 } & & 1 & 2 & 3 & 4 & 5 & 6 & 7 \\
\hline $\mathrm{FO}_{1}$ & Konsistensi & $\mathrm{K}+$ & $\mathrm{K}+$ & $\mathrm{K}+$ & $\mathrm{K}+$ & $\mathrm{K}+$ & $\mathrm{K}+$ & $\mathrm{K}+$ \\
& Warna & Putih & Putih & Putih & Putih & Putih & Putih & Putih \\
& Bau & - & - & - & - & - & - & - \\
\hline $\mathrm{FO}_{2}$ & Konsistensi & $\mathrm{K}++$ & $\mathrm{K}++$ & $\mathrm{K}++$ & $\mathrm{K}++$ & $\mathrm{K}++$ & $\mathrm{K}++$ & $\mathrm{K}++$ \\
& Warna & Putih & Putih & Putih & Putih & Putih & Putih & Putih \\
& Bau & - & - & - & - & - & - & - \\
\hline $\mathrm{FO}_{3}$ & Konsistensi & $\mathrm{K}+++$ & $\mathrm{K}+++$ & $\mathrm{K}+++$ & $\mathrm{K}+++$ & $\mathrm{K}+++$ & $\mathrm{K}+++$ & $\mathrm{K}+++$ \\
& Warna & Putih & Putih & Putih & Putih & Putih & Putih & Putih \\
& Bau & - & - & - & - & - & - & - \\
\hline
\end{tabular}

Keterangan :

$\mathrm{K}+\quad$ : agak kental

$\mathrm{K}++\quad$ : kental

$\mathrm{K}+++$ : lebih kental

: tidak berbau

\section{Hasil Formulasi dan Pengujian Kualitas Fisik Basis dan Sediaan Krim}

Dari proses formulasi, dihasilkan sediaan krim F1, F2 dan F3. Semua formula dibuat dengan menggunakan Viscolam AT100P, yang merupakan polimer golongan poliakrilat dengan fungsi sebagai pengental. Polimer ini dapat digunakan sebagai emulgator/emulsifier untuk senyawa lipofilik dalam jumlah kecil. Pada penelitian ini, formulasi krim menggunakan senyawa aktif berupa ekstrak tanaman yang memiliki kelarutan yang rendah dalam air, sehingga penggunaan viscolam sebagai basis krim sangat menguntungkan, karena berfungsi sebagai pengental, sekaligus emulsifier. Propilen glikol, selain dimaksudkan sebagai humektan, juga digunakan sebagai pengencer ekstrak pada saat awal pembuatan. Penggunaan pengawet metil parabenpropil paraben dengan jumlah total 0,9 merupakan hasil optimasi, karena bahan aktif dari bahan alam memiliki resiko lebih besar untuk ditumbuhi mikroba.

Hasil penelitian menunjukkan bahwa formula krim memiliki karateristik organoleptis yang berbeda. Semakin tinggi konsentrasi ekstrak, maka kekentalan dan intensitas warna krim semakin meningkat. Basis dan ketiga krim tidak mengalami perubahan bentuk, konsistensi, warna dan bau selama penyimpanan 30 hari pada suhu kamar (Tabel 4). 
Tabel 4. Hasil Pengamatan Organoleptis Sediaan Krim Selama 30 Hari

\begin{tabular}{clllllll}
\hline & Karakteristik & \multicolumn{6}{c}{ Perubahan pada hari ke- } \\
\cline { 3 - 7 } Formula & & 1 & 3 & 7 & 14 & 21 & 30 \\
\hline \multirow{2}{*}{ F1 } & Konsistensi & - & - & - & - & - & - \\
& Warna & - & - & - & - & - & - \\
& Bau & - & - & - & - & - & - \\
\hline \multirow{2}{*}{ F2 } & Konsistensi & - & - & - & - & - & - \\
& Warna & - & - & - & - & - & - \\
& Bau & - & - & - & - & - & - \\
\hline \multirow{2}{*}{ F3 } & Konsistensi & - & - & - & - & - & - \\
& Warna & - & - & - & - & - & - \\
& Bau & - & - & - & - & - & - \\
\hline
\end{tabular}

Keterangan:

- : tidak ada perubahan

Dari data perubahan $\mathrm{pH}$, diketahui bahwa $\mathrm{pH}$ basis dan sediaan krim berkisar antara 4,0-8,0 selama penyimpanan 30 hari (Gambar 1). Data perubahan $\mathrm{pH}$ dianalisis secara statistik menggunakan desain blok lengkap, dengan taraf kepercayaan sebesar $95 \%$ ( $\alpha$ $=0,05 \%)$. Hipotesis nol $\left(\mathrm{H}_{0}\right)$ menunjukkan tidak ada perbedaan $\mathrm{pH}$ yang nyata antar sediaan krim, sedangkan hipotesis satu $\left(\mathrm{H}_{1}\right)$ menunjukkan ada perbedaan $\mathrm{pH}$ yang nyata antar formula sediaan krim. $\mathrm{H}_{0}$ akan ditolak, bila $\mathrm{F}_{\text {hitung }} \geq \mathrm{F}_{\text {tabel }}$. Dari hasil analisis statistik, $H_{0}$ ditolak, karena $F_{\text {hitung }}(140,851)>F_{\text {tabel }}(2,75)$. Dengan diterimanya $H_{1}$, maka dilakukan uji lanjutan berupa Uji Tuckey. Dari uji ini didapatkan bahwa F1 (Formula 1) merupakan sediaan krim dengan perubahan $\mathrm{pH}$ terbaik.

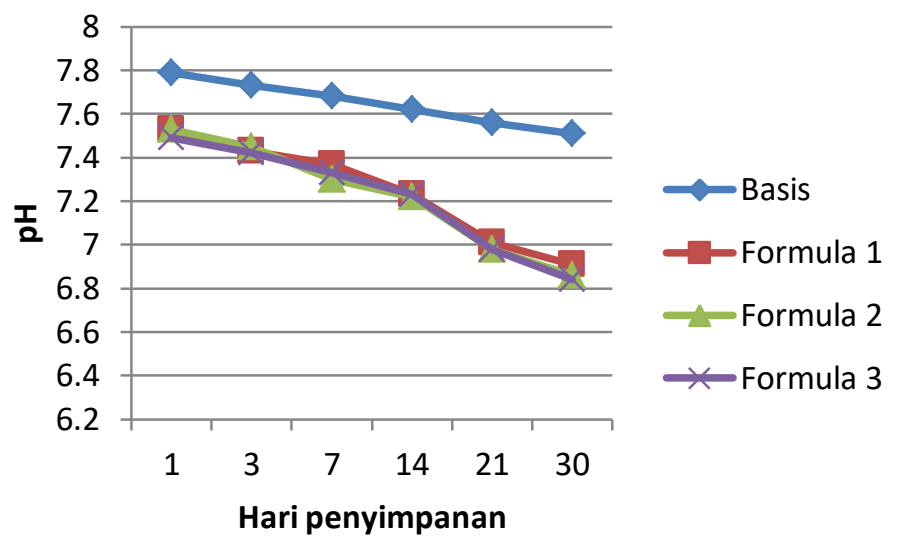

Gambar 1. Perubahan $\mathrm{pH}$ basis dan sediaan krim selama 30 hari 
Dari data perubahan viskositas, diketahui bahwa viskositas basis dan ketiga sediaan krim mengalami sedikit penurunan selama penyimpanan 30 hari (Gambar 2). Data perubahan viskositas dianalisis secara statistik menggunakan desain blok lengkap, dengan taraf kepercayaan sebesar $95 \%(\alpha=0,05 \%)$. Hipotesis nol $\left(H_{0}\right)$ menunjukkan tidak ada perbedaan tinggi busa yang nyata antar formula sediaan krim, sedang hipotesis satu $\left(\mathrm{H}_{1}\right)$ menunjukkan adanya perbedaan tinggi yang nyata antar formula sediaan krim. $\mathrm{H}_{0}$ akan ditolak, bila $\mathrm{F}_{\text {hitung }} \geq \mathrm{F}_{\text {tabel. }}$. Dari analisis statistik, diketahui bahwa $\mathrm{H}_{0}$ ditolak, karena $\mathrm{F}_{\text {hitung }}(48,357)>\mathrm{F}_{\text {tabel }}(2,75)$. Dengan diterimanya $\mathrm{H}_{1}$, maka dilakukan uji lanjutan berupa Uji Tuckey. Dari uji ini didapatkan bahwa F1 merupakan sediaan krim dengan perubahan viskositas terbaik.

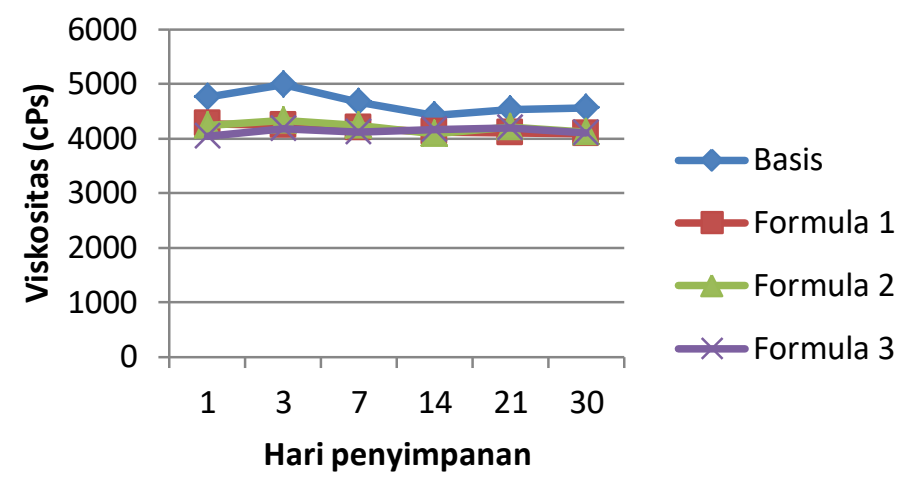

Gambar 2. Perubahan viskositas basis dan sediaan krim selama 30 hari

Dari data pemisahan emulsi ketiga sediaan krim tidak mengalami pemisahan fase, setelah disentrifugasi pada kecepatan $3.750 \mathrm{rpm}$, sehingga dinyatakan stabil selama satu tahun. Hasil pengujian kualitas fisik sediaan krim menunjukkan bahwa F1 merupakan sediaan krim dengan perubahan organoleptis, $\mathrm{pH}$ dan viskositas terbaik dan stabil selama satu tahun.

\section{Hasil Pengujian Aktivitas Antibakteri Sediaan Krim Selama Penyimpanan}

Dari penentuan aktivitas, diketahui bahwa aktivitas antibakteri ketiga sediaan krim cenderung stabil selama penyimpanan 30 hari (Tabel 5).

Tabel 5. Hasil Pengujian Aktivitas Antibakteri Sediaan Krim terhadap Bakteri Uji Selama 30 Hari

\begin{tabular}{|c|c|c|c|c|c|c|}
\hline \multirow[t]{3}{*}{ Formula } & \multicolumn{6}{|c|}{ Diameter hambat $(\mathrm{cm})$ terhadap } \\
\hline & \multicolumn{3}{|c|}{ S. epidermidis ATCC 12228} & \multicolumn{3}{|c|}{ P. acnes isolat klinik } \\
\hline & Hari-ke1 & $\begin{array}{c}\text { Hari ke- } \\
14\end{array}$ & Hari ke-30 & Hari-ke1 & $\begin{array}{c}\text { Hari ke- } \\
14\end{array}$ & Hari ke-30 \\
\hline 1 & 1,66 & 1,67 & 1,66 & 1,87 & 1,86 & 1,86 \\
\hline 2 & 1,84 & 1,82 & 1,83 & 1,92 & 1,93 & 1,92 \\
\hline 3 & 1,90 & 1,90 & 1,92 & 2,06 & 2,05 & 2,05 \\
\hline
\end{tabular}


Hasil Uji Banding Aktivitas Antibakteri Sediaan Krim terhadap Basis dan Ekstrak

Dari hasil uji banding, diketahui bahwa basis krim tidak menunjukkan aktivitas antibakteri. Aktivitas antibakteri Formula 1, Formula 2 dan Formula 3 terhadap $S$. epidermidis ATTC 12228 dan P. acnes isolat klinik lebih besar dibandingkan ekstraknya (Tabel 6)

Tabel 6. Hasil Uji Banding Aktivitas Antibakteri Basis, Sediaan Krim dan Ekstrak terhadap Bakteri Uji

\begin{tabular}{lcc}
\hline Bahan uji & \multicolumn{2}{c}{ Diameter hambat (cm) terhadap } \\
\cline { 2 - 3 } & S. epidermidis ATCC 12228 & P. acnes isolat klinik \\
\hline Basis $\mathrm{F}_{2}$ & - & - \\
\hline Formula 1 & 1,66 & 1,87 \\
Formula 2 & 1,81 & 1,92 \\
Formula 3 & 1,90 & 2,06 \\
\hline Ekstrak & 1,12 & 1,15 \\
& 1,16 & 1,19 \\
& 1,21 & 1,24 \\
\hline
\end{tabular}

\section{Pembahasan}

Daun kapuk segar diekstraksi dengan metode maserasi, karena metode ini mudah dan tidak memerlukan suhu tinggi, sehingga tidak merusak senyawa-senyawa termolabil. Etanol 95\% digunakan sebagai penyari, karena simplisia berupa daun segar dengan kandungan air yang tinggi ${ }^{12}$.

Dari hasil uji aktivitas antibakteri, diketahui bahwa ekstrak masih memiliki aktivitas terhadap kedua bakteri uji sampai konsentrasi $10 \% \mathrm{~b} / \mathrm{v}$, sehingga digunakan kosentrasi larutan stok sebesar 8 dan $10 \%$ b/v untuk penentuan KHTM. Nilai KHTM ekstrak terhadap P. acnes isolat klinik lebih kecil dibandingkan S. epidermidis ATTC 12228. Hal ini menunjukkan bahwa ekstrak etanol daun kapuk memiliki aktivitas lebih besar terhadap P. acnes dibandingkan S. epidermidis ATTC 12228.

Aktivitas antibakteri ekstrak etanol daun kapuk diduga berasal dari berbagai senyawa bioaktifnya, yaitu senyawa alkaloid, polifenol, tanin, flavonoid, saponin, steroid dan kuinon. Hal ini sesuai dengan penelitian terdahulu bahwa ekstrak air dan etanol daun kapuk mengandung senyawa polifenol, tanin, saponin, gula tereduksi, poliuronoid dan plobatanin ${ }^{11}$. Penelitian lainnya menunjukkan berbagai ekstrak batang dan daun kapuk mengandung senyawa alkaloid, tanin, flavonoid, saponin, steroid aglikon, glikosida, protein, karbohidrat, gula tereduksi, vitamin $\mathrm{A}$ dan vitamin $\mathrm{E}^{8}$. 
Alkaloid, flavonoid dan steroid yang diisolasi dari tumbuhan diketahui mempunyai aktivitas antimikroba terhadap organisme patogen. Ketiga golongan senyawa ini juga berfungsi sebagai antioksidan, antidiare, anti inflamasi dan penghambat enzim ${ }^{16-27}$. Tanin umumnya memiliki aktivitas antimikroba yang kuat terhadap ragi, jamur dan bakteri. Tanin juga dapat mengendapkan protein, menginaktivasi adhesin dan protein transpor sel serta berikatan dengan logam dan makromolekul lainnya, sehingga mikroorganisme akan kekurangan senyawa tersebut ${ }^{28}$.

Berdasarkan analisis statistik diketahui bahwa $\mathrm{pH}$ semua sediaan krim berubah selama masa penyimpanan, namun masih memenuhi persyaratan $\mathrm{pH}$ sediaan topikal, yaitu 4,0-8,029. Viskositas semua sediaan krim berubah selama masa penyimpanan, namun masih memenuhi persyaratan viskositas sediaan topikal $(4000-40.000 \mathrm{cPs})^{29}$. Penurunan $\mathrm{pH}$ disebabkan adanya senyawa aktif dari ekstrak yang bersifat asam, sehingga berpengaruh pada Viscolam AT100P. Polimer ini merupakan golongan akrilat yang memiliki sifat dipengaruhi oleh $\mathrm{pH}$ lingkungannya.

Sesuai teori, sediaan krim yang tidak mengalami pemisahan fase, setelah disentrifugasi pada kecepatan $3.750 \mathrm{rpm}$ selama 5 jam, dapat diasumsikan stabil selama satu tahun ${ }^{30}$.

Pengujian aktivitas antibakteri sediaan krim bertujuan untuk mengetahui aktivitas antibakterinya selama penyimpanan 30 hari. F3 yang memiliki aktivitas terbaik terhadap P. acnes isolat klinik dibandingkan terhadap S. epidermidis ATTC 12228. Diameter hambat sediaan krim meningkat seiring dengan jumlah penambahan ekstrak. Dari hasil uji banding diketahui bahwa ada peningkatan aktivitas ketiga sediaan krim dibanding ekstraknya, padahal basisnya tidak memiliki aktivitas. Peningkatan aktivitas ini diduga berasal dari interaksi ekstrak dengan salah satu komponen dalam basis krim, yang menyebabkan peningkatan aktivitas antibakterinya.

\section{Kesimpulan.}

Dari penelitian ini diperoleh kesimpulan bahwa Formula 1 (krim dengan 2x KHTM ekstrak) merupakan sediaan krim dengan kualitas fisik terbaik, karena tampilan organoleptis, $\mathrm{pH}$ dan viskositasnya stabil selama 30 hari pada suhu kamar serta tidak mengalami pemisahan fase selama satu tahun. Formula 3 (krim dengan 4x KHTM ekstrak) merupakan sediaan krim dengan aktivitas antibakteri terbaik, terutama terhadap $P$. acnes isolat klinik.

\section{Daftar Pustaka}

1. Dunn LK, O'Neill JL, Feldman SR. Acne in adolescents: Quality of life, self- esteem, mood, and psychological disorders. Dermatol Online J. 2011;17(1):1.

2. Esmail A, Hassan MG, Amer MM, Abdelrahman S, Hamed AM, Abd-raboh HA, et al. Antimicrobial activity of certain natural-based plant oils against the antibioticresistant acne bacteria. Saudi Journal of Biological Sciences. 2020;27:448-55. 
3. Dréno B, Pécastaings $S$, Corvec S, Veraldi S, Khammari A, Roques C. Cutibacterium acnes (Propionibacterium acnes) and acne vulgaris: a brief look at the latest updates. J Eur Acad Dermatol Venereol. 2018;32(S2):5-14.

4. Zaenglein AL, Pathy AL, Schlosser BJ, Alikhan A, Baldwin HE, Berson DS, et al. Guidelines of care for the management of acne vulgaris. J Am Acad Dermatol. 2016;74:945-73.

5. Farrah G, Tan E. The use of oral antibiotics in treating acne vulgaris: a new approach. Dermatol. Ther. 2016;29(5):377-84.

6. Eichenfield L. Evolving perspective on the etiology and pathogenesis of acne vulgaris. J Drugs Dermatol. 2015;14:263-68.

7. Neamsuvan O, Kama A, Salaemae A, Leesen S, Waedueramae N. A survey of herbal formulas for skin diseases from Thailand's three southern border provinces. J Herb Med. 2015;5:190-8.

8. Njokuocha RC, Ewinike AE. Antibacterial and phytochemical properties of crude leaf extract of Moringa oleifera Lam., Pterocarpus santalinoides L'Herit DC and Ceiba pentandra L. on some clinical bacteria isolates in Nigeria. Journal of Complementary and Alternative Medical Research. 2020;10(4):1-15.

9. Anosike CA, Ogili OB, Nwankwo ON, Eze EA. Phytochemical screening and antimicrobial activity of the petroleum ether, methanol and ethanol extracts of Ceiba pentandra stem bark. Journal of Medicinal Plants Research. 2012;6(46):5743-47.

10. Lawal TO, Mbanu AE, Adeniyi BA. Inhibitory activities of Ceiba pentandra (L.) Gaertn. and Cordia sbestena Linn. on selected rapidly growing mycobacteria. African Journal of Microbiology Research. 2014;8(24):2387 - 92.

11. Asare P, Oseni LA. Comparative evaluation of Ceiba pentandra ethanolic extract, stem bark extract and the combination thereof for in vitro bacterial growth inhibition. J Nat Sci Res. 2012; 2(5); 44-50.

12. Milanda T, Kusuma ASW, Shanmuganathan K. Antibacterial activity of malacca fruit (Phyllanthus emblica L.) ethanolic extract and fraction againts Bacillus cereus FNCC0057 and Shigella dysentriae ATCC13313. Asian J Pharm Clin Res. 2017; Special Issue (May):8-10.

13. Balouiri M, Sadiki M, Ibnsouda SK, Methods for in vitro evaluating antimicrobial activity: a review. J Pharm Anal. 2016;6(2):71-9.

14. Departemen Kesehatan RI. Formularium Nasional. Edisi Kedua. Jakarta:Departemen Kesehatan Republik Indonesia. 1978.

15. Navindgikar N, Kamalapurkar KA, Chavan PS, Formulation and evaluation of multipurpose herbal cream. International Journal of Current Pharmaceutical Research. 2020;12(3);25-30.

16. Ahmad A, Kaleem M, Ahmed Z, Shafiq H. Therapeutic potential of flavonoids and their mechanism of action against microbial and viral infections-A review. Food Research International. 2015;77:221-235.

17. Cushnie TPT, Cushnie B, Lamb AJ. Alkaloids: An overview of their antibacterial, antibiotic-enhancing and antivirulence activities. International Journal of Antimicrobial Agents. 2014;44:377-86.

18. Hryniewicka A, Malinowska M, Hauschild T, Pieczul K, Morzycki JW. Synthesis and antimicrobial properties of steroid-based imidazolium salts. The Journal of Steroid Biochemistry and Molecular Biology. 2019;189:65-72. 
19. Okpo SO, Ching FP, Ekeleme IC. Evaluation of the anti-diarrhoeal activity of the aqueous extract from leaves of Pterocarpus santalinoides. Research Journal of Pharmaceutical, Biological and Chemical Sciences. 2011;2(3):590 - 597.

20. Emencheta SC, Enweani IB, Oli AN, Okezie UM, Attama AA. Evaluation of antimicrobial activities of fractions of plant parts of Pterocarpus santalinoides. Biotechnology Journal International. 2019;23(3):1-11.

21. Odeh IC, Tor-Anyiin TA. Phytochemical and antimicrobial evaluation of leaf-extracts of Pterocarpus santalinoides. European Journal of Medicinal Plants. 2014;4(1):105115.

22. Osuntokun OT, Ajayi Ayodele O, Adeoye MI, Odufunwa AE. Assessment of antimicrobial and phytochemical properties of crude leaf and bark extracts of Ceiba pentandra on selected clinical isolates found in Nigerian teaching hospital. Journal of Bacteriology and Mycology Open Access. 2017;4(1):17-23.

23. Obi CF, Nzeakor TA, Okpala MI, Ezeha IO, Nwobi LG, Omeje MO, Ezeokonkwo RC. Evaluation of antitrypanosomal activity of Pterocarpus santalinoides L'H'erit ex DC hydroethanol leaf extract in rats experimentally infected with Trypanosoma brucei. Journal of Ethnopharmacology, 2019;243:112085.

24. Odeh IC, Tor-Anyiin TA, Igoli JO, Anyam JV. In vitro antimicrobial properties of friedelan-3-one from Pterocarpus santalinoides L'Herit, ex Dc. African Journal of Biotechnology. 2016;15(14):531-538.

25. Osuagwu GGE, Akomas CB. Antimicrobial activity of leaves of three species of Nigerian Pterocarpus (Jacq). International Journal of Medicinal and Aromatic Plants. 2013;3(2):178 - 183.

26. Vanhauteghem D, Janssens GPJ, Lauwaerts A, Sys S, Boyen F, Cox E, et al. Exposure to the proton scavenger glycine under alkaline conditions induces Escherichia coli viability loss. PLoS ONE, 2013;8(3):603-28.

27. Chelliah R, Ramakrishnan S, Antony U. Nutritional quality of Moringa oleifera for its bioactivity and antibacterial properties. International Food Research Journal. 2017;24(2):825-833.

28. Zhu C, Lei M, Andargie M, Zeng J, Li J. Antifungal activity and mechanism of action of tannic acid against Penicillium digitatum. Physiological and Molecular Plant Pathology, 2019;107:46-50.

29. Aulton M. Pharmaceutics: The science of dosage form design. Edirberd, London: Curchill Livingstone. 1988.

30. Lachman L, Lieberman HA, Kanig JL. Teori dan Praktek Farmasi Industri. Jilid II. Edisi Ketiga. Penerjemah: Siti Suyatmi. Jakarta:UI-Press. 1994. 